\title{
Following Europe's lead, Congress moves to ban ape research
}

For all the monkey business in Washington, DC, US lawmakers have decided to get serious about protecting chimpanzees. But doing so creates a conundrum: although the apes are intelligent and caring creatures, they are also considered by many to be the best animal model for developing a vaccine for hepatitis $\mathrm{C}$, a human liver disease that leads to nearly 350,000 deaths each year worldwide.

The only large-scale effort to use chimps for such research is in the US. A bill now under consideration by Senate and House committees would put a stop to much of that work; the Great Ape Protection Act would nix "invasive" research on chimpanzees, bonobos, gorillas, orangutans and gibbons. It defines 'invasive' as "any research that may cause death, bodily injury, pain, distress, fear, injury or trauma to a great ape"-effectively ending all but some behavioral research on the animals. This would mean retirement to sanctuaries for approximately 1,000 chimps living in US research labs.

"When we can find alternatives to animal research, we do. But hepatitis A and B vaccines both stemmed from work with these animals, and they're our best way of developing one for C," says William Talman, president of the Federation of American Societies for Experimental Biology, an umbrella organization that represents 23 biological and medical research societies.

The hepatitis $\mathrm{C}$ virus does not cause liver disease in the chimps; however, those exposed to it commonly carry it throughout their lives. Meanwhile, the virus does not survive well-and so is difficult to study-in other species, with the exception of humans. A January report from the US Institute of Medicine, entitled "Hepatitis and Liver Cancer: a National Strategy for Prevention and Control of Hepatitis B and C," puts an emphasis on chimpanzee research for developing a vaccine.

Talman points out that the apes used in such research commonly live ten or more years longer than their counterparts in the wild and that the care the animals receive is strictly regulated.

Proponents of the bill, however, aren't convinced. "The world as a whole is moving toward the idea that it's not right to use intelligent animals in this way," says Kathleen Conlee, director of Program Management, Animal Research Issues for the Humane Society of the United States. "But, even if you don't agree with that as a principle, there's a more tangible argument: it's literally not worth it."

\section{Counting costs}

The Humane Society and other proponents of the bill assert that the cost of keeping the chimpanzees in a research setting outweighs the value of the research. Using numbers garnered by the US National Institutes of Health database known as RePORTER, the Humane Society estimates that $\$ 173$ million in federal funding could be saved by moving chimps out of costly research settings and into sanctuaries. She also points to recent reviews, such as a study published in the Journal of Medical Primatology (39, 9-23, 2010), that question the effectiveness of chimp hepatitis C studies.
"It's been nearly three decades since the development of the hepatitis B vaccine," Conlee says. "Maybe it's time we started to put a focus on newer techniques."

The bill has garnered considerable support since its introduction last year to the House of Representatives, where it now has 150 cosponsors. A version of the bill was introduced to the Senate in August.

Given the turbulence introduced to congressional proceedings by the midterm elections, it is not clear when the bill is likely to be put to a vote. However, Conlee hopes that Congress will ultimately follow the European Parliament's lead. On 8 September, the Parliament passed a set of new rules governing use of laboratory animals that bans the use of great apes.

The decision was probably a relatively simple one for the parliament, Talman says, but it won't be for Congress. "There was basically no research on great apes in the EU, anyway," he says. "It's easy to make certain, very vocal, groups happy by banning something that you're not doing-especially if you know that the research is happening here."

Stu Hutson

\section{Correction \\ In the September 2010 issue of Nature Medicine, the article entitled 'Personalized investigation' (Nat. Med. 16, 953, 2010) misspelled the last name of Mike Cariaso as Cariaaroso in one instance. The error has been corrected in the HTML and PDF versions of the article.}

supposedly protecting it from heat and ultraviolet light. Biomatrica claims that its products will enable blood samples to be stored at room temperature for up to three years. Purified RNA will have a shelf life of at least 12 years, and for purified DNA it's at least 30 years.

According to Rolf Müller, Biomatrica's chief scientific officer, health insurance giant Kaiser Permanente is already banking on Biomatrica's technology; it's using Biomatrica's DNA preservation matrix, DNAStable, to build a biobank of samples from 500,000 patients.

\section{Cool cash}

However it's implemented, moving away from freezer storage on the large scale could have some distinct advantages. The costs associated with running laboratory freezers - for both the lab budget and the environment-are steep. Dry storage could provide a viable way to cut back. Biomatrica conducted a study in conjunction with Stanford University's Sustainability and Energy Management office. The report estimated that replacing the freezers with dry storage would cut its energy usage by 40 million kilowatt-hours, eliminate 18,000 metric tons of carbon emissions per year and save $\$ 16$ million over the next ten years.

There's also the security factor- although many institutions have failsafe systems and backup generators, accidents still happen.

Hogan, who co-founded GenVault, was a professor of biotechnology at the Baylor College of Medicine in Houston when the city was assailed by Tropical Storm Allison. As a result of a monthlong power outage, Hogan lost all his samples of human DNA, tissue and proteins, as did most of his colleagues.

"It was no accident that Mitch Eggers and I founded GenVault early in 2002 within six months of Allison," says Hogan. "The loss was very fresh in our minds."

Roxanne Palmer 